University of Nebraska - Lincoln

DigitalCommons@University of Nebraska - Lincoln

Publications, Agencies and Staff of the U.S.

Department of Commerce

U.S. Department of Commerce

2003

\title{
LOW FREQUENCY CALLS OF BRYDE'S WHALES
}

Erin M. Oleson

University of California - Davis, eoleson@ucsd.edu

Jay Barlow

NOAA Fisheries, jay.barlow@noaa.gov

Jonathan Gordon

University of St Andrews

Shannon Rankin

NOAA Fisheries

John A. Hildebrand

University of California - San Diego

Follow this and additional works at: https://digitalcommons.unl.edu/usdeptcommercepub

Part of the Environmental Sciences Commons

Oleson, Erin M.; Barlow, Jay; Gordon, Jonathan; Rankin, Shannon; and Hildebrand, John A., "LOW FREQUENCY CALLS OF BRYDE'S WHALES" (2003). Publications, Agencies and Staff of the U.S. Department of Commerce. 298.

https://digitalcommons.unl.edu/usdeptcommercepub/298

This Article is brought to you for free and open access by the U.S. Department of Commerce at DigitalCommons@University of Nebraska - Lincoln. It has been accepted for inclusion in Publications, Agencies and Staff of the U.S. Department of Commerce by an authorized administrator of DigitalCommons@University of Nebraska - Lincoln. 
MARINE MAMMAL SCIENCE, 19(2):407-419 (April 2003)

(C) 2003 by the Society for Marine Mammalogy

\title{
LOW FREQUENCY CALLS OF BRYDE'S WHALES
}

\author{
ERIN M. Oteson \\ Scripps Institution of Oceanography, \\ University of California, San Diego, La Jolla, California 92093, U.S.A. \\ E-mail: eoleson@ucsd.edu \\ JAY BARLOW \\ Southwest Fisheries Science Center, NOAA Fisheries, \\ P. O. Box 27l, La Jolla, California 92037, U.S.A. \\ JONATHAN GORDON \\ Sea Mammal Research Unit, \\ Gatty Marine Laboratory, \\ University of St Andrews, \\ St Andrews, Fife KY16 8LB, Scotland \\ SHANNON RANKIN \\ Southwest Fisheries Science Center, NOAA Fisheries, \\ P. O. Box 271, La Jolla, California 92037, U.S.A. \\ John A. Hildebrand \\ Scripps Institution of Oceanography, \\ University of California, San Diego, \\ La Jolla, California 92093, U.S.A.
}

Despite significant effort, only two published reports describe Bryde's whale (Balaenoptera edeni) calls (Cummings et al. 1986, Edds et al. 1993). In both studies fundamental call frequencies were greater than $90 \mathrm{~Hz}$, somewhat higher than the call frequencies attributed to other balaenopterids (Clark 1990, Edds-Walton 1997). Through opportunistic acoustic recordings, we obtained and analyzed numerous examples of Bryde's whale calls from three habitats: the Eastern Tropical Pacific (ETP), the southern Caribbean, and the northwest Pacific near the coast of Japan. In all but a single case, call frequencies of $60 \mathrm{~Hz}$ or less were observed.

Bryde's whales maintain a tropical and subtropical distribution worldwide (Fig. 1) (Omura 1959, Reilly and Thayer 1990, Wade and Gerrodette 1993). They generally remain in waters warmer than $15^{\circ}-20^{\circ} \mathrm{C}$ around the world, limiting their range to latitudes between $40^{\circ} \mathrm{N}$ and $40^{\circ} \mathrm{S}$ (Omura and Nemoto 1955). Long migrations are not typical of Bryde's whales, though limited shifts in distribution toward and away from the equator, in winter and summer, respectively, have been observed (Cummings 1985). They are the most common baleen whale in each of the regions discussed in this paper (Omura and Nemoto 1955, Casinos 1986, Wade and Gerrodette 1993, Kishiro 1996, Debrot et al. 1998, Romero et al. 2001.). 


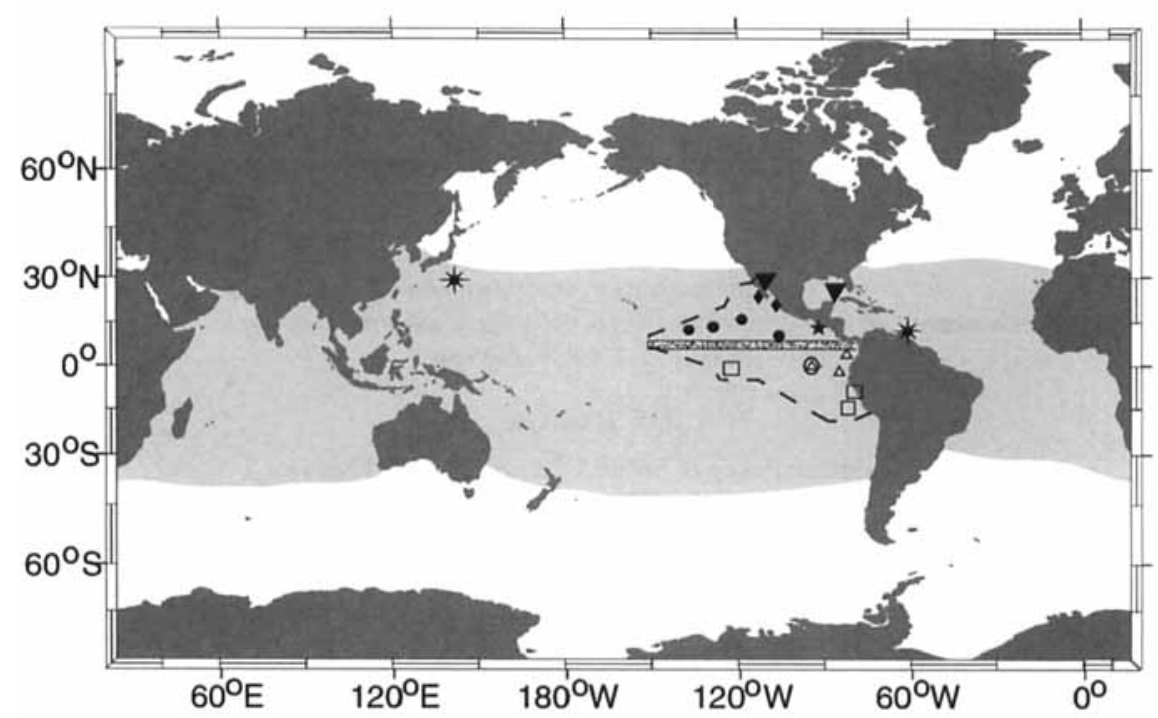

Figure 1. Locations where Bryde's whale vocalization have been recorded worldwide. Known distribution of Bryde's whales indicated by light gray shaded region. Previously reported call types indicated with triangle $(\boldsymbol{\nabla})$, new recordings, reported here from Japan and southern Caribbean, indicated by star $(*)$. Calls recorded from Eastern Tropical Pacific are represented by its own symbol to show geographic variability. Six different call types recorded from July to December in Eastern Tropical Pacific (including west coast of Baja California). Hiatus in species' distribution between $7^{\circ}$ and $9^{\circ} \mathrm{N}$ (Wade and Gerrodecte 1993) shown as stippled region. Our acoustic dara supports this boundary with three call types recorded north of the boundary: $\bullet=\mathrm{Be} 2,-\mathrm{Be} 4$, and $\star=\mathrm{Be} 5$, and three call types detected south: $\Delta=\mathrm{Be} 1, \square=\mathrm{Be} 3$, and $O=\mathrm{Be} 6$. ETP study area boundary shown as dashed line.

Cummings $e t$ al. (1986) recorded calls from Bryde's whales on two occasions near Loreto, Mexico, in the Gulf of California, one from a visually confirmed Bryde's whale, and the other from a whale believed to be Bryde's based on the similarity of the calls to those previously recorded (Cummings et al. 1986). These calls averaged $0.4 \mathrm{sec}$ duration at $124 \mathrm{~Hz}$, often with a slightly up or downswept character ( $\Delta \mathrm{f}=$ $15 \mathrm{~Hz}$ ). Call source level estimates ranged between 152 and $174 \mathrm{~dB}$ re $\mu \mathrm{Pa}$ at $1 \mathrm{~m}$.

Edds $t$ al. (1993) compared calls from free-ranging adult and adult-calf paits of Bryde's whales, and from a captive juvenile. The captive juvenile, stranded in the Gulf of Mexico on the coast of Florida, produced short duration, amplitude and frequency modulated moans $(200-900 \mathrm{~Hz})$, as well as discrete pulses $(400-610$ $\mathrm{Hz}$ ), occurring before, during, and after moans. Free-ranging adults and adultcalf pairs in the Gulf of California teportedly produced three separate call types (Table 1). The locations of previous recordings and our new recordings are shown in Figure 1.

\section{New Recordings}

Eastern Tropical Pacific-Bryde's whale calls in the ETP were obtained during National Marine Fisheries Service Southwest Fisheries Science Center (SWFSC) 


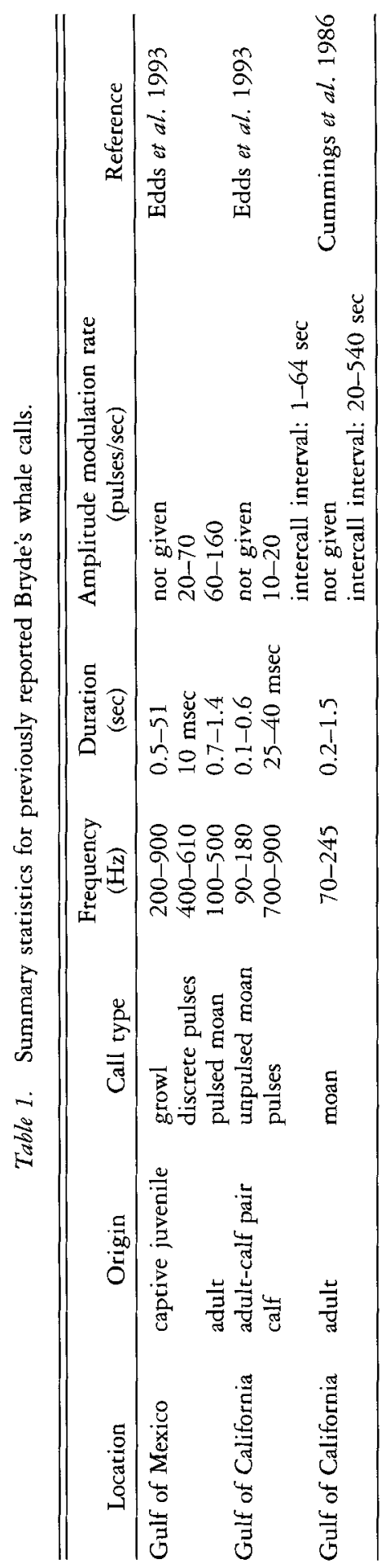


dolphin assessment surveys aboard NOAA vessels David Starr Jordan and McArthur between July and December of 1999 and 2000. DIFAR (Directional Fixing and Ranging) sonobuoys (type AN-SSQ 53D) were deployed on probable and confirmed Bryde's whale sightings whenever possible. Operable sonobuoys were deployed on 19 of 50 Bryde's whale sightings in 1999, and on 16 of 57 sightings in 2000 . All whales identified in this paper as "Bryde's whale" have been positively identified by experienced marine mammal observers. The closest point of observer approach was always less than $2 \mathrm{~km}$, and was generally less than $500 \mathrm{~m}$. "Probable Bryde's whale" refers to whales that were classified as Bryde's/sei because the blow and dorsal fin were observed simultaneously, separating these species from larger balaenopterids, but the rostral ridges that separate Bryde's and sei whales (B. borealis) were not seen. All of these "probable Bryde's" sightings were outside the known geographic range of sei whales.

Each recording was monitored between 0 and $1,000 \mathrm{~Hz}$ for $45 \mathrm{~min}$ or until the sonobuoy signal had degraded. Using the directional capabilities of the sonobuoys, we computed bearings to low-frequency signals observed during Bryde's whale sightings and compared them to the visually determined position of the animal or group. We determined the bearing angle to the source using a suite of acoustic processing software specifically designed for use with DIFAR sonobuoys (McDonald et al. 2000). DIFAR sonobuoys contain an omnidirectional acoustic sensor and obtain directionality information from two orthogonal velocity sensors and a magnetic compass. The signals from each component are multiplexed together within the sonobuoy and transmitted via a single radio carrier frequency to an antenna mounted on the ship. Sonobuoy signals were monitored with a commercially available spectral analysis software package (SpectraPLUS). When a signal of interest was detected it was demultiplexed and bearing angles to the sound source were computed using the DIFAR localization software.

The bearing angle of each call was compared to the location of the Bryde's whale determined from sighting records of distance and bearing from the ship. Generally one DIFAR sonobuoy was deployed on each sighting, providing a direction from the buoy to the sound source. When the direction and amplitude derived for the acoustic signal was consistent with the position of the animal, the signal was attributed to the Bryde's whale.

We acoustically monitored 31 confirmed Bryde's and six probable Bryde's sightings during the ETP dolphin surveys yielding $21.7 \mathrm{~h}$ of recording. Thirteen recordings $(35 \%)$ contained calls. There were 104 calls detected corresponding to known Bryde's whale locations over the total $21.7 \mathrm{~h}$. The locations of all ETP Bryde's whale calls are shown in Figure 1, and summary statistics are listed in Table 2.

We identified six different call types associated with Bryde's whale during the ETP surveys. The most abundant call type detected was a complex two-part, frequency modulated call (Be1, Table 2; Fig. 2A), recorded on three occasions from sonobuoys deployed between $0^{\circ}-3^{\circ} \mathrm{N}$ and $86^{\circ} 24^{\prime}-94^{\circ} 20^{\prime} \mathrm{W}$. The call began with an upper-frequency component at approximately $37 \mathrm{~Hz}$. While the upper tone continued, a lower-frequency downswept tone began at approximately $23 \mathrm{~Hz}$. The lower component generally swept for an average of $4 \mathrm{~Hz}$ and lasted for an average of 


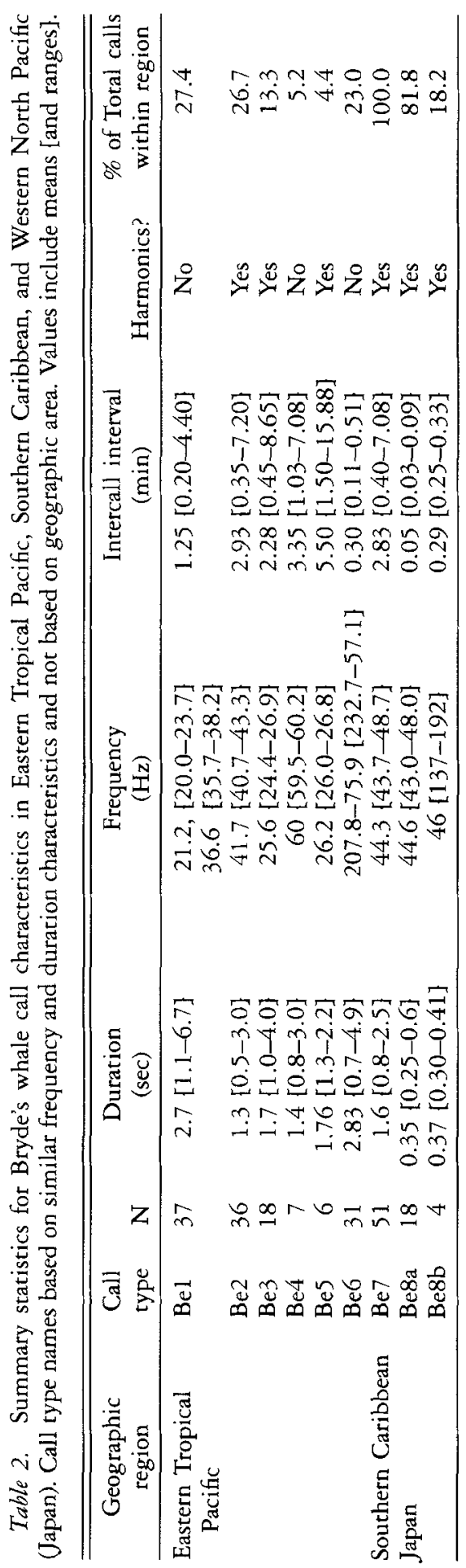



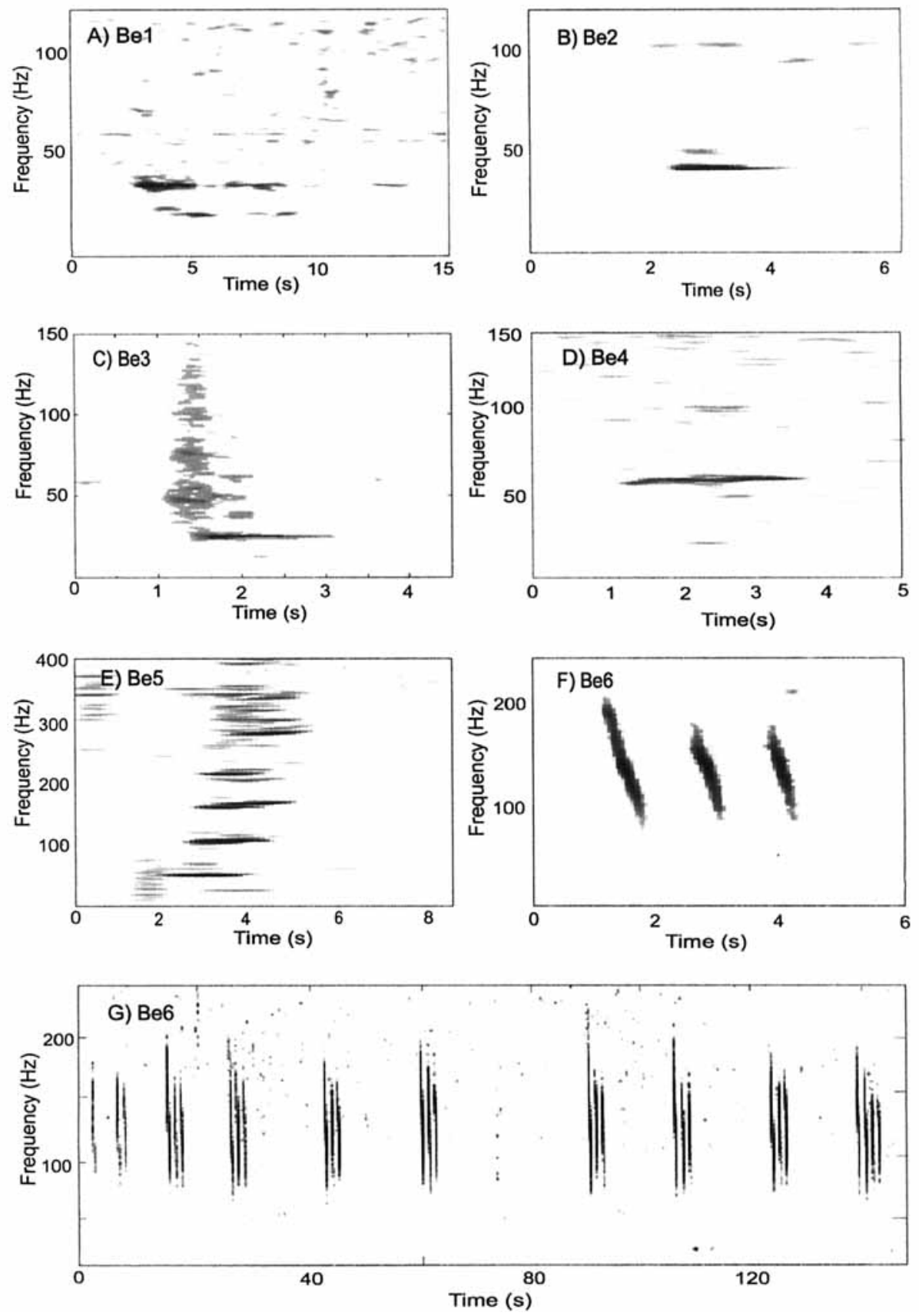

Figure 2. Bryde's whale call types of eastern tropical Pacific, observed from DIFAR sononbuoys: (A) Be1, (B) Be2, (C) Be3, (D) Be4, (E) Be5, (F) Be6, and (G) series of Be6 calls showing increase in number of sweeps as calling bout progresses. Signals not corrected for frequency response of sonobuoys, which roll off at $10 \mathrm{~dB}$ per octave below $1 \mathrm{kHz}$. 
$2 \mathrm{sec}$, while the upper component had variable duration, occasionally extending beyond the end of the lower-frequency component. Occasionally, the signal continued for several seconds with an alternation between the upper and lower components with decreasing amplitude, though it is not clear if the continuation represents multipath arrivals or an actual continuation of the call. These calls were rapidly repeated with an average intercall interval of $1.25 \mathrm{~min}$.

The non-harmonic structure of the call and its variable total duration may suggest that call Bel is an example of countercalling between two animals in close proximity, with the first whale producing the upper frequency and the second whale answering at the lower frequency. However, we believe that the entire call was produced by a single animal because of the consistent interval between the start of the two parts, and because of the consistent amplitude relationship between the upper and lower components. During at least one sighting at which Bel was recorded, the whales were separated by no less than $0.9 \mathrm{~km}$. If the call itself represented countercalling, we would expect there to be more apparent changes in amplitude between the upper and lower components and the interval between the start of the two components. Although we believe that call type Be1 is a single call, it is clear from the bearings to the calls of one sighting that the whales were countercalling, with each Bel call representing part of a countercall sequence.

During one sighting when the Bel call type was recorded, another call was also detected. Call type Be6 (Table 2, Fig. 2F) was recorded at $1^{\circ} 30^{\prime} \mathrm{N}, 94^{\circ} 20^{\prime} \mathrm{W}$ and consisted of a grouping of downsweeps, with one to four sweeps per call. Each sweep extended from an upper frequency of $208 \mathrm{~Hz}$ to $76 \mathrm{~Hz}$. There was generally about $0.5 \mathrm{sec}$ between sweeps, and the number of sweeps per call increased throughout a calling bout, such that the first call of a series contained a single sweep, and the last call might have three or four sweeps (Fig. 2G). The duration of the call was on average $2.8 \mathrm{sec}$, with an intercall interval of $18 \mathrm{sec}$. The bearings to the Be6 signals indicated that a single animal or group of very tightly associated animals were producing this call while traveling at a fairly constant speed and direction. Single sweeps with similar characteristics to this call have previously been attributed to minke whales (B. acutorostrata) in the northwest Atlantic and near Australia (Edds-Walton 1997, Gedamke et al. 2001). We do not believe that a minke whale produced the calls reported here for several reasons. Minke whales are only occasional inhabitants of the waters near the Galapagos Islands and are generally uncommon in the eastern tropical Pacific, with only seven sightings during SWFSC surveys in the region since 1986, and no sighting of a minke whale in the vicinity of this recording (Wade and Gerrodette 1993, Kinzey et al. 2001). Calls that have been attributed to minke whales have not occurred in rhythmic patterns such as that demonstrated here, nor have they occurred in groups of more than a single sweep. In addition, the bearings to these calls matched the location and direction of travel of the Bryde's whales.

Another common call detected from Bryde's whales in the ETP (Be2, Table 2; Fig. 2B) had an average frequency of $41.7 \mathrm{~Hz}$ and lasted $1.3 \mathrm{sec}$. It was detected on four sonobuoy deployments between $9^{\circ} 30^{\prime}-17^{\circ} \mathrm{N}$ and $108^{\circ} 15^{\prime}-140^{\circ} 30^{\prime} \mathrm{W}$. The call was occasionally detected with a series of two to four harmonics up to $160 \mathrm{~Hz}$. 
These calls were repeated at a moderately rapid rate, occurring on average every 3 min of recording. This call was heard only during encounters with lone Bryde's whales.

We recorded three other call types from ETP Bryde's whales. At $25.6 \mathrm{~Hz}$ and 1.7-sec duration, a tonal call (Be3, Table 2, Fig. 2C) occurred on four different sonobuoy deployments throughout the ETP. At one location, two to three harmonics were observed above this call. A $60 \mathrm{~Hz}$, non-harmonic call (Be4, Table 2, Fig. 2d) was observed on two occasions along the southwest coast of the Gulf of California. The call lasted approximately $1.4 \mathrm{sec}$ and recurred about every $3.5 \mathrm{~min}$. Both $\mathrm{Be} 3$ and $\mathrm{Be} 4$ were recorded from lone individuals and pairs of whales. One call type occurred on only a single occasion, at $14^{\circ} 54^{\prime} \mathrm{N}, 93^{\circ} 12^{\prime} \mathrm{W}$, repeated at an average interval of $6 \mathrm{~min}$. This upswept call lasted for $1.8 \mathrm{sec}$ and had a fundamental frequency of $26.2 \mathrm{~Hz}$ (Be5, Table 2, Fig. 2E). There were consistently at least four strong harmonics present, with as many as eight harmonics evident on some calls. This call was recorded from a lone Bryde's whale.

Surveys in the ETP study area were restricted to the late summer and fall, preventing inference about the variation of call types throughout the year. However, the spatial separation of the Bryde's whale call types by latitude is evidene (Fig. 1). Three of the call types reported here ( $\mathrm{Be} 2,4$, and 5) were observed only north of $9^{\circ} \mathrm{N}$, and three (Bel, 3, and 6) were observed only south of $5^{\circ} \mathrm{N}$. Wade and Gerrodette (1993) suggested the division of the ETP Bryde's whales into two stocks based on a hiatus in the species distribution between $7^{\circ}$ and $9^{\circ} \mathrm{N}$, shown in Figure 1. Assuming Bryde's whale stocks have distinctive acoustic behaviors, our data are supportive of the stock division suggested from visual survey data reported by Wade and Gerrodette (1993).

Soutbern Caribbean-Bryde's whale calls were recorded in the Southern Caribbean during the NMFS Southeast Fisheries Science Center (SEFSC) Windwards 2000 Humpback Survey in February and March of 2000 aboard the NOAA vessel Gordon Gunter. DIFAR sonobuoys were continuously deployed to detect and monitor humpback whale songs (McDonald $e t$ al. 2000). The DIFAR sonobuoy signals were monitored and bearing angles determined using the same procedures described previously for the ETP. The presence of all cetaceans was recorded during visual observations and the detection of unidentified acoustic signals was noted for later analysis. During post-processing, we monitored recordings corresponding to Bryde's whale sightings for $45 \mathrm{~min}$, computed bearings of low-frequency signals, and compared them to the recorded position of Bryde's sightings.

There were five confirmed Bryde's whale sightings and one probable Bryde's whale sighting off the coast of Venezuela (Swartz and Burks 2000). Two of the confirmed Bryde's whale sightings, and the probable Bryde's whale sighting, were associated with low-frequency acoustic signals on DIFAR sonobuoys, and acoustic bearing angles corresponding to the visually determined positions of the animals. Four of the Bryde's whale sightings were of an animal pair and one sighting was of a lone animal. Mother-calf pairs were sighted on two occasions, but were not heard vocalizing. There were 31 total calls detected during three Bryde's whale 


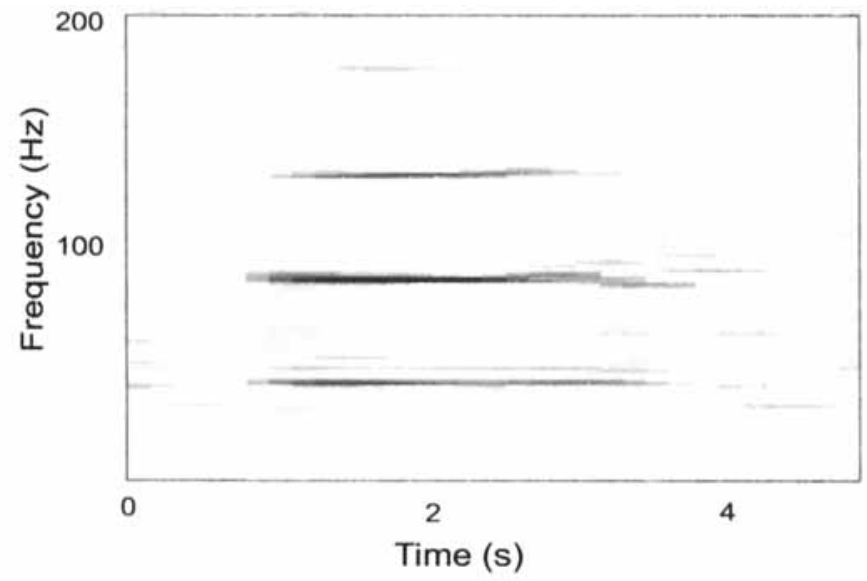

Figure 3. Southern Caribbean Bryde's whale call (Be7) detected on DIFAR sonobuoys in three locations north of Venezuela during February, 2000.

encounters. The acoustic recordings from all six Bryde's whales were monitored for a total of $4.5 \mathrm{~h}$ and yielded an average of 6.9 calls $/ \mathrm{h}$ across all recordings.

Only one call type was detected from southern Caribbean Bryde's whales. The call had a fundamental frequency of $44 \mathrm{~Hz}$ and consistently had two or three harmonics, though rarely as many as four harmonics (Be7, Table 2; Fig. 3) potentially due to the proximity of the animal to the sonobuoy. The second harmonic was generally stronger and was often detected before the start of the fundamental. The call ranged in duration between 0.8 and $2.5 \mathrm{sec}$ and occurred with an average intercall interval of $2.8 \mathrm{~min}$. All acoustic detections with concurrent sightings occurred along the north coast of Venezuela from $10^{\circ} 46^{\prime} \mathrm{N}$ to $12^{\circ} 2^{\prime} \mathrm{N}$ and $62^{\circ} 03^{\prime} \mathrm{W}$ to $66^{\circ} 36^{\prime} \mathrm{W}$, near Isla de Margarita and the Peninsula de Paria, a region where Bryde's whales are known to be abundant (Casinos 1986), perhaps associated with the strong upwelling along the east shore of Isla de Margarita (Sturm, 1991).

The southern Caribbean Bryde's whale call type (Be7) was detected on three occasions where visual confirmation of the source was not possible. The three locations were: (1) along both shores of the Araya Peninsula of Venezuela west of Isla de Margarita, (2) along the eastern coast of Trinidad, and (3) along the southwest coast of Barbados. The locations of all acoustic detections of Bryde's whale calls are consistent with the known distribution of Bryde's whales in the Caribbean (Romero et al. 2001). No other marine mammals were seen corresponding to the location of these calls, though humpback whales (Megaptera novaeangliae), bottlenose dolphins (Tursiops truncatus), spotted dolphins (Stenella frontalis), and common dolphins (Delphinus spp.) were occasionally seen in the general vicinity of the hydrophone.

Nortbwest Pacific - Bryde's whale calls were recorded near the coast of Japan while videotaping them for a documentary. The precise date of the recordings were not provided, however the recordings are known to have occurred between June and 

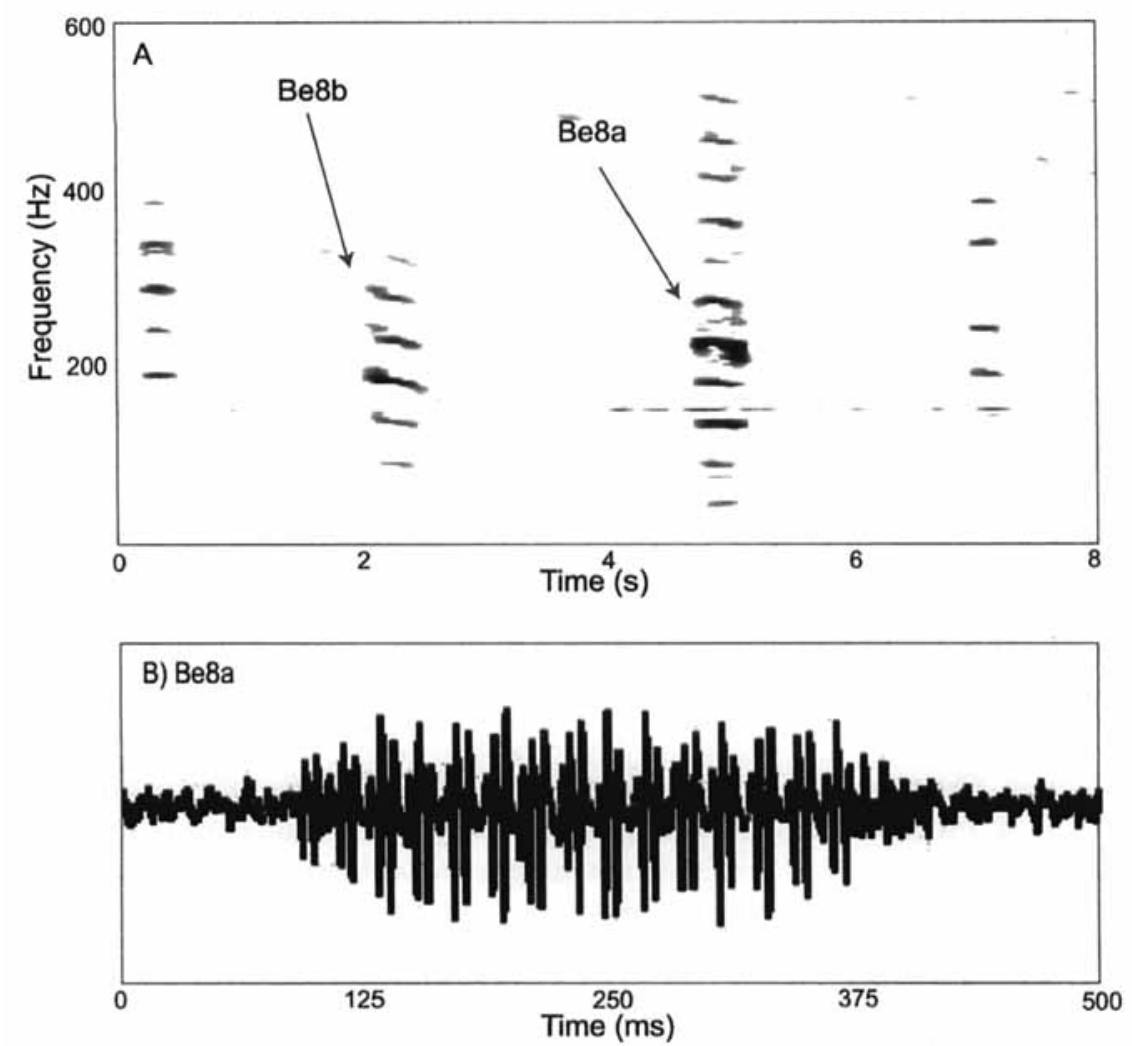

Figure 4. (A) Bryde's whale calls recorded from multiple whales off the coast of Japan in Northwest Pacific Ocean. Two call types shown differ only in that Be8b is not pulsed and is slightly downswept. (B) Wave form representation of Be8a clearly shows these pulses within the call.

August. The sounds were recorded by a Sea System hydrophone onto the audio track of the video camera, and later transferred to Digital Audio Tape (DAT) for analysis and archiving. Approximately one minute of the videotape recording was made available for analysis of the calls.

In $63 \mathrm{sec}$ of recording we detected 22 calls, consisting of two very similar call types. The calls included higher-frequency harmonics than those found in other regions reported here, although this might have been a consequence of the extremely close proximity at which these recordings were made. The most common call type was a pulsed moan with a fundamental frequency of approximately $45 \mathrm{~Hz}$ (Be8a, Table 2, Fig. 4). Each moan consisted of approximately 13 pulses, with an average of 51.6 pulses/sec (Fig $4 \mathrm{~B}$ ). All calls were less than 0.6 -sec duration. In some calls the fundamental frequency was not detected but could be inferred from the spacing of the harmonics. We detected as many as nine harmonics on some calls, with an upper frequency of $418 \mathrm{~Hz}$, although most calls contained only five to seven harmonics with the third and fourth harmonics generally the strongest components. The apparent higher energy in these bands may have been due to a low 
end roll-off $(>50 \mathrm{~Hz})$ in the recording system, (inferred from the low ambient noise levels below $50 \mathrm{~Hz}$ relative to the ambient noise levels in the rest of the band). These Northwest Pacific calls had an intercall interval of $2.9 \mathrm{sec}$, and they occurred more frequently than those in other regions over the monitoring period, though it is not known whether this represents a high local density of animals or a high calling rate.

The less frequent call type (Be8b, Table 2, Fig. 4) was a downswept, shortduration call with several harmonics. On four occurrences the fundamental frequency component was $46 \mathrm{~Hz}$, with the third and fourth harmonics of higher intensity than the lower frequencies, again, likely due to the roll-off of the recording system. The average intercall interval for this call type was $17.3 \mathrm{sec}$. The approximate location of the Northwest Pacific Bryde's whale recording is shown in Figure 1.

\section{Conclusions}

Bryde's whales produce low-frequency tonal and swept calls similar to the calls of other balaenopterid species. These signals vary in frequency, duration, modulation, and the presence or absence of harmonics. Because these variations appear geographically coherent, these calls may be useful in studying population structure. Although the calls vary regionally, they do maintain common characteristics consistent with other Balaenopterid calls. Specifically, all but one of the call types reported here have a fundamental frequency below $60 \mathrm{~Hz}$, all last from one-quarter of a second to several seconds, and they are produced in extended sequences. None of the calls reported from the ETP or the southern Caribbean were produced by cow-calf pairs, or by lone juveniles. The presence of two distinct, simultaneous, and harmonically unrelated frequencies in a single Bryde's whale call suggest the possibility of two independent, yet simultaneously excited resonance modes in this species.

The description of Bryde's whale calls reported here are significantly different from previously reported call types. The calls described here have very lowfrequency components ( $60 \mathrm{~Hz}$ or less), and are generally tonal, with only one call type recorded near the coast of Japan containing pulses, and one call from the ETP consisting of repetitious downsweeps. Previously published reports on Bryde's whale calls have reported higher-frequency calls. The lowest frequency detected for a captive juvenile from the Gulf of Mexico was $200 \mathrm{~Hz}$, however, a low end roll-off of $100 \mathrm{~Hz}$ in the recording system would have prevented the recording of lower frequency calls (Edds et al. 1993). Bryde's whales in the Gulf of California have been reported to produce sounds as low as $70 \mathrm{~Hz}$ (Cummings et al. 1986), while a calf was heard vocalizing at frequencies as high as $900 \mathrm{~Hz}$ (Edds et al. 1993), significantly higher than the frequencies reported here. Several of the sounds previously reported for Bryde's whales by Cummings et al. (1986) and Edds $e t$ al. (1993) were produced by juvenile whales or by cow-calf pairs, while these groups appear to be silent in our analysis. Our recordings from the mouth of the Gulf of California were made in August, while Cummings recorded vocalizations farther north in the Gulf in June; therefore, it is possible that different portions of the population were sampled by the two studies, yielding different call types. 
In the ETP there seems to be a relationship between group size, behavior, and call detection for four call types. Call type Bel was detected only from groups of Bryde's whales, while two other calls $(\mathrm{Be} 2, \mathrm{Be} 5)$ were recorded only from lone whales. It is also notable that $\mathrm{Be} 1$ was observed on one occasion from multiple whales in a group, in a countercall type of pactern, with one whale producing the Bel call type, followed by another Bel from a different whale some time later. During the 45-min monitoring period the calls detected by these whales maintained consistent bearings from the sonobuoy, perhaps indicating that the whales were not moving in a particular direction nor with significant speed. These whales were separated by at least $1.7 \mathrm{~km}$. During the same encounter another whale was producing the Be 6 call type while traveling at a consistent speed and direction. It is not possible to say what the purpose of these call types are, especially given our limited sample size and the absence of detailed behaviotal information. However, it seems likely that these calls are used for different purposes because of their observed relationship with group size and behavior. The sex of the calling animals was not determined for any of the call types in any of the regions reported here. Determining the sex of calling animals should be a priority for future studies and might reveal the extent to which these calls function as sexual displays.

\section{ACKNOWLEDGMENTS}

Douglas Nowacek, Mark McDonald, Chris Clark, Sara Heimlich, and an anonymous reviewer deserve special thanks for providing helpful comments on previous drafts of this paper. We would like to thank SWFSC Chief Scientist Lisa Balance, all the ETP dolphin observers, cruise leaders, acousticians, officers, and crew for facilitating our recordings. Recordings of Bryde's whales in the ET'P were made by Megan Ferguson, Laura Morse, and Julie Oswald. SEFSC Chief Scientists Steven Swartz and Tim Cole, as well as the observers, crew, and officers in the southern Caribbean survey deserve thanks for their help with this work. Anthony Martinez and Analisa Tam aided with recordings of Bryde's whales in the southern Caribbean. Kyusoku Iwamoto recorded the Bryde's whales near Japan, and Naoko Funahashi graciously provided them for our analysis. Charles Greene of Greeneridge Sciences and Mark McDonald developed and provided the DIFAR demultiplexing and directionfinding software necessary for the directional analysis of the DIFAR sonobuoy signals.

\section{Literature Cited}

Casinos, A. 1986. La fauna de cetaceos del Caribe suboriental. Pages $42-55$ in H. P. Castelo, ed. Acras de la Primera Reunion de Trabajos de Expertos en Mammiferos Acuaticos de America del Sur, Buenos Aires, Argentina.

Clark, C. W. 1990. Acoustic behavior of mysticete whales. Pages 571-583 in J. Thomas and R. Kastelein, eds. Sensory abilities of cetaceans. Plenum Press, New York, NY.

Cummings, W. C. 1985. Bryde's whale. Pages $137-154$ in S. H. Ridgeway, S.H., and R. Harrison, eds. Handbook of marine mammals. Volume 3 . The Sirenians and baleen whales. Academic Press, San Diego, CA.

Cummings, W. C., P. O. Thompson and S. J. HA. 1986. Sounds from Bryde, Balaenoptera edeni, and finback, B. physalus, whales in the Gulf of California. Fishery Bulletin, U.S. 84:359-380.

Debrot, A., J. A. De Mlyer and P. J. E. Dezentje. 1998. Additional records and a review of cetacean fauna of the Leeward Dutch Antilles. Caribbean Journal of Science 34:204210 . 
EdDS, P., P. K. Odell AND B. R. Tershy. 1993. Calls of a captive juvenile and free-ranging adult-calf pairs of Bryde's whales, Balaenoptera edeni. Marine Mammal Science 9:269284.

EdDs-WaLton, P. L. 1997. Acoustic communication signals of mysticete whales. Bioacoustics 8:47-60.

Gedamke, J., D. P. Costa AND A. Dunstan. 2001. Localization and visual verification of complex minke whale vocalizations. Journal of the Acoustical Society of America 109:3038-3047.

Kinzey, D., T. Gerrodette, A. Dizon, W. Perryman, P. Olson and S. Rankin. 2001. Marine mammal data collected during a survey in the eastern tropical Pacific Ocean aboard the NOAA ships McArthur and David Starr Jordan, July 28-December 9, 2000. NOAA Technical Memorandum NMFS-SWFSC-303. Available from SWFC, P. O. Box 271, La Jolla, CA 92038.

KishiRo, T. 1996. Movements of marked Bryde's whales in the Western North Pacific. Report of the International Whaling Commission 40:421-428.

McDonald, M., E. M. Oleson and J. A. HiLdebrand. 2000. Windwards 2000, Acoustics Cruise Report. NOAA Technical Memorandum NMFS- SEFSC-441. 31 pp. Available from SEFC, 75 Virginia Beach Dr., Miami, FL 33149.

Omura, H. 1959. Bryde's whales from the coast of Japan. Scientific Reports of the Whales Research Institute, Tokyo 14:1-33.

Omura, H., And T. Nemoto. 1955. Sei whales in the adjacent waters of Japan. III. Relation between movement and water temperature of the sea. Scientific Reports of the Whales Research Institute, Tokyo 10:79-87.

ReILIY, S. B., AND V. G. ThaYer. 1990. Blue whale (Balaenoptera musculus) distribution in the eastern tropical Pacific. Marine Mammal Science 6:265-277.

Romero, A., A. I. Agudo, S. M. Green and G. N. di Sciara. 2001. Cetaceans of Venezuela: Their distribution and conservation status. NOAA Technical Report NMFS 151. $60 \mathrm{pp}$.

SrURM, M. G. DE L. 1991. The living resources of the Caribbean Sea and adjacent regions. Caribbean Marine Studies 2:18-44.

SwartZ, S., AND C. BurKs. 2000. Cruise results Windwards humpback (Megaptera novaeangliae) survey, NOAA ship Gordon Gunter Cruise GU-00-01, 9 February to 3 April. NOAA Technical Memorandum NMFS-SEFSC-438. 31 pp. Available from SEFC, 75 Virginia Beach Dr., Miami, FL 33149.

WADE, P. R., AND T. GERRODETTE. 1993. Estimates of cetacean abundance and distribution in the Eastern Tropical Pacific. Report of the International Whaling Commission $43: 477-493$. 